\title{
Pseudocystocolonic fistula in chronic pancreatitis: an atypical diagnosis by capsule colonoscopy
}

\author{
Vítor Macedo Silva (D) , 1,2,3 Tiago Cúrdia Gonçalves, 1,2,3 Pedro Boal Carvalho, 1,2,3 \\ José Cotter ${ }^{1,2,3}$
}

${ }^{1}$ Gastroenterology Department, Hospital da Senhora da Oliveira, Guimaraes, Portugal

${ }^{2}$ Life and Health Sciences Research Institute (ICVS), School of Medicine, University of Minho, Braga, Portugal ${ }^{3}$ ICVS/3B'S, PT Government Associate Laboratory, Braga / Guimarães, Portugal

\section{Correspondence to Dr Vítor Macedo Silva; vitorbmacedo@gmail.com}

Accepted 8 February 2022

\section{DESCRIPTION}

A 57 years old man with alcoholic chronic pancreatitis complicated with a pancreatic pseudocyst was admitted for fever and epigastric pain for the previous week. Abdominal CT on admission revealed four intra-abdominal cystic collections, the largest in the left hypochondrium with $12 \times$ $2.5 \mathrm{~cm}$ (figure 1). The gaseous content inside the collection, as well as a thickening of the splenic flexure of the colon, raised the hypothesis of a pseudocystocolonic fistula, despite not being clearly observed on CT images. The patient was hospitalised and treated with broad spectrum antibiotic meropenem. ${ }^{1}$ The patient had previously undergone colonoscopy for colorectal cancer screening, which was incomplete because of iatrogenic risk due to significant rigidity on the sigmoid colon. Because of this, in the setting of an unconfirmed pseudocystocolonic fistula, the patient was proposed for capsule colonoscopy (CC).$^{2}$ CC revealed a large orifice near the splenic flexure, compatible with the suspected fistula (figure 2A,B). The capsule entered this orifice for some seconds, capturing images of a cavity with inflamed walls (figure 2C) and spontaneously returned to the colon. The patient reported capsule exteriorisation a few hours later. The patient continued antibiotics and was proposed to left hemicolectomy, which had no complications. The patient is still asymptomatic, 12 months after surgery.

To our knowledge, this is the first case reporting a pseudocystocolonic fistula diagnosis by using capsule endoscopy. Despite being conducted to complete colorectal cancer screening, the use

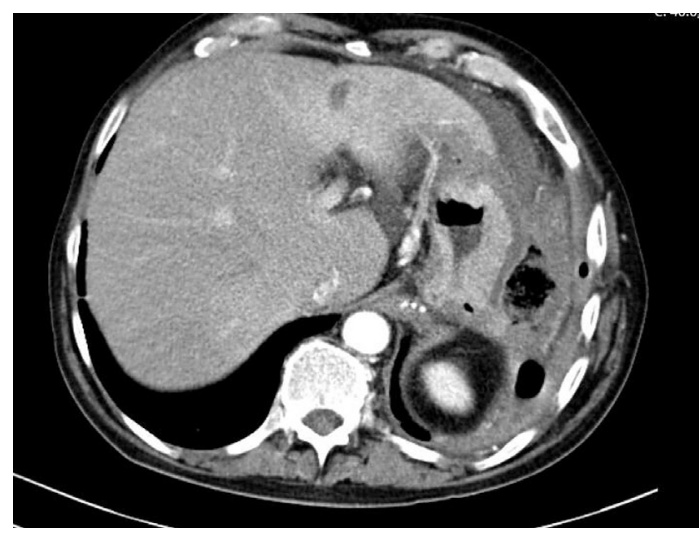

Figure 1 Abdominal CT revealing a cystic collection with gaseous content on the left hypochondrium.

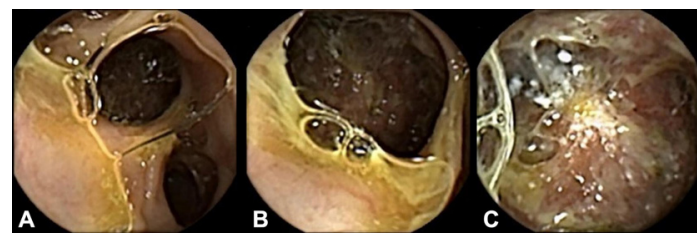

Figure 2 (A) Capsule colonoscopy frame showing a simultaneous view of pseudocystocolonic fistula and colonic lumen. (B) Capsule colonoscopy frame with a closer view of pseudocystocolonic fistula. (C) Capsule colonoscopy frame with a view inside pseudocyst cavity.

\section{Patient's perspective}

In my perspective, my life has gained a lot more quality. After performing capsule endoscopy which conducted to being submitted to surgery, I do not currently experience frequent abdominal pain and fever as I did before, and I have been able to gain more weight which was previously very difficult for me. It was a long process but it eventually made my health status significantly better.

\section{Learning points}

Pancreatic fistulas are a possible complication in chronic pancreatitis, and may be difficult to identify in standard abdominal CT.

- Capsule colonoscopy is indicated for colorectal cancer screening in patients in which conventional colonoscopy is incomplete.

- The performance of capsule colonoscopy was of utmost importance, since it led to a definitive diagnosis and ultimately to the decision of abdominal surgical treatment.

of CC in this patient conducted to an unusual yet decision-changing finding. The decision of performing CC in this patient was of utmost importance, since it led to a definitive diagnosis and ultimately to the decision of abdominal surgical treatment.

Contributors VMS was responsible for the patient management during his hospitalisation and for the manuscript construction. TCG and PBC reviewed and validated capsule colonoscopy images, and critically revised the manuscript. JC critically revised and approved the final version of the manuscript. 


\section{Images in...}

Funding The authors have not declared a specific grant for this research from any funding agency in the public, commercial or not-for-profit sectors.

Competing interests None declared.

Patient consent for publication Consent obtained directly from patient(s).

Provenance and peer review Not commissioned; externally peer reviewed.

Case reports provide a valuable learning resource for the scientific community and can indicate areas of interest for future research. They should not be used in isolation to guide treatment choices or public health policy.
ORCID iD

Vítor Macedo Silva http://orcid.org/0000-0001-8001-9067

\section{REFERENCES}

1 Sağlamkaya U, Mas MR, Yaşar M, et al. Penetration of meropenem and cefepim into pancreatic tissue during the course of experimental acute pancreatitis. Pancreas 2002;24:264-8

2 Spada C, Hassan C, Bellini D, et al. Imaging alternatives to colonoscopy: CT colonography and colon capsule. European Society of Gastrointestinal Endoscopy (ESGE) and European Society of Gastrointestinal and Abdominal Radiology (ESGAR) Guideline - Update 2020. Eur Radiol 2021;31:2967-82.

Copyright 2022 BMJ Publishing Group. All rights reserved. For permission to reuse any of this content visit

https://www.bmj.com/company/products-services/rights-and-licensing/permissions/

BMJ Case Report Fellows may re-use this article for personal use and teaching without any further permission.

Become a Fellow of BMJ Case Reports today and you can:

- Submit as many cases as you like

- Enjoy fast sympathetic peer review and rapid publication of accepted articles

Access all the published articles

Re-use any of the published material for personal use and teaching without further permission

\section{Customer Service}

If you have any further queries about your subscription, please contact our customer services team on +44 (0) 2071111105 or via email at support@bmj.com.

Visit casereports.bmj.com for more articles like this and to become a Fellow 